\title{
Sistem Pendukung Keputusan Pemilihan Forum Mahasiswa dengan Metode Weighted Product
}

\author{
Lia Farokhah', Adriani Kala'lembang ${ }^{2}$ \\ ${ }^{1,2}$ STMIK ASIA Malang \\ ${ }^{1}$ farokhah@asia.ac.id, ${ }^{2}$ adriani.riny@gmail.com
}

\begin{abstract}
ABSTRAK. Pemilihan forum bagi mahasiswa untuk mencari sebuah forum yang berkualitas dan bisa menjawab permasalahan yang mereka hadapi tentang tema perkuliahan merupakan hal yang tidak mudah. Umumnya, mahasiswa atau pengguna menghadapi kebingungan dengan banyaknya variasi forum di media internet. Pada penelitian ini, dirancang sistem pendukung keputusan pemilihan forum mahasiswa dalam memberikan solusi pemilihan forum terbaik. Metode yang digunakan pada studi kasus ini adalah Weighted Product dengan kriteria yang dipakai adalah tanggal posting, jumlah jawaban (answer), jumlah orang yang melihat (views) dan perangkingan dari situs Alexa. Hasil pengujian dari aplikasi mampu menyeleksi alternatif terbaik untuk pemilihan forum. Dalam hal ini, alternatif yang dimaksud yaitu hasil rekomendasi forum yang akan direkomendasikan ke mahaasiswa berdasarkan pembobotan kriteriakriteria yang ditentukan. secara umum, Hasil dari empat pengujian validasi dan verifikasibisa disimpulkan bahwa forum yang direkomendasikan sudah sesuai dengan pembobotan yang dilakukan yaitu dengan nilai keakuratan sebesar 100\%.
\end{abstract}

Kata Kunci: MADM, Weighted Product, Sistem Pendukung Keputusan, Forum

\begin{abstract}
The Selection of forums for students to find a quality forum and can answer their problems that they face about the theme of the lecture is not easy. Generally, students or users face confusion with the many variations of forums on the internet media. In this study, the decision support system designed the selection of student forums in providing the best forum selection solution. The method used in this case study is Weighted Product with the criteria used are the date of posting, the number of answers (answer), the number of people who see (views) and ranking from the Alexa site.

Test results from the application are able to select the best alternative for forum selection. In this case, the alternative is the recommendation of the forum that will be recommended to the students based on the weighting of the criteria specified. In general, the results of the four tests wirh verification and validation testing can be concluded that the recommended forum is in accordance with the weighting that is done with the value of accuracy of $100 \%$.
\end{abstract}

Keywords: MADM, Weighted Product, Decision Support System, Forum

\section{PENDAHULUAN}

Forum merupakan salah satu media komunikasi dalam sebuah kelompok.Forum terdiri dari beberapakelompok orang yang berbagi informasi.Pengguna forum biasanya mem-posting sebuah bahasan dan nantinya ada umpan balik dari para member atau nonmember yang menanggapi.Hal ini tergantung hak akses yang diberikan.Dalam forum biasanya kita mencari berbagai macam hal khususnya sebuah informasi yang kita butuhkan misalnya forum jual beli, forum untuk tempat belajar, forum yang bisa menjawab pertanyaan dari masalah yang sedang kita hadapi dan masih banyak lagi.Keberadaan forum di media internet sangat banyak dan beragam. Hal ini menyebabkan pengguna bingung untuk memilih forum yang akan dipilih. Dalam menghadapi kebingungan terkadang bisa saja pengguna menyasar pada forum-forum yang tidak jelas, forum tidak produktif, dan forum kurang terpercaya.Dimana pada akhirnya tidak menemukan jawaban masalah yang dibutuhkan.

Pemilihan forum secara acak atau random sering dilakukan dikarenakan kurangnya informasi terhadap forum-forum mana yang memiliki kualitas bagus. Pengguna lebih banyak mencari melalui bantuan search engine atau memilih forum-forum yang paling sering didengar saja. Disisi lain, ada banyak forum yang bisa menjadi pilihan.

Secara umum, bentuk forum yang ada masih dalam bentuk satu portal dengan satu pengelola.Penelitian yang dilakukan mencoba untuk memberikan suatu bantuan rekomendasi forum secara otomatis dengan kriteria tertentu melalui sistem perangkingan dalam menunjang keputusan. Disisi lain, akan membantu pengguna memotong waktu pencarian forum satu persatu terhadap forum-forum yang ada di internet.Tema yang diambil adalah pencarian forum mahasiswa tentang pencarian e-learnng. Metode Perangkingan dan pengambilan keputusan yang dipakai adalah Weighted Product.Weighted Product merupakan salah satu metodeMulti-Attribute Decision Making(MADM) (Kusumadewi, 2006).Terdapat kriteria yang menjadi acuan 
dalam penelitian rekomendasi forum yaitu tanggal posting, jumlah jawaban (answer), jumlah orang yang melihat (views) dan perangkingan dari situs Alexa.

Hasil dari metode yang digunakan adalah perangkingan.Hal ini menjadi masukan kepada mahasiswa dalam mengambil keputusan dalam pemilihan forum.Rekomendasi yang diberikan didasarkan pembobotan tertinggi berdasarkan kriteria nilai yang telah dimasukkan.

\section{LANDASAN TEORI}

\subsection{Pengertian Sistem Pendukung Keputusan (SPK)}

Definisi SPK secara sederhana adalah sebuah sistem yang digunakan sebagai alat bantu menyelesaikan masalah untuk membantu pengambil keputusan (manajer) dalam menentukan keputusan tetapi tidak untuk menggantikan kapasitas manajer hanya memberikan pertimbangan. Turban (2005) menyatakan SPK ditujukan untuk keputusan-keputusan yang memerlukan penilaian atau pada keputusan-keputusan yang sama sekali tidak dapat didukung oleh algoritma. Definisi ini belum memberikan gambaran secara spesifik bahwa SPK berbasis komputer dan akan beroperasi online interakif, maka dari itu muncul berbagai definisi mengenai SPK.

Little (1970) mendefenisikan SPK sebagai sekumpulan prosedur berbasis model untuk data pemrosesan dan penilaian guna membantu para namajer mengambil keputusan. Dia menyatakan bahwa untuk sukses, sistem tersebut haruslah sederhana, cepat, mudah dikontrol, adaftif, lengkap dengan isu-isu penting, dan mudah berkomunikasi.

Bonczek (1980) mendefenisikan SPK sebagai sistem berbasis komputer yang terdiri dari tiga komponen yang saling berinteraksi: sistem bahasa (mekanisme untuk memberikan komunikasi antara pengguna dan komponen SPK lain), sitem pengetahuan (repositori pengetahuan domain masalah yang ada pada SPK baik sebagai data atau sebagai prosedur), dan sistem pemrosesan masalah (hubungan antara dua komponen lainnya, terdiri dari satu atau lebih kapabilitas manipulasi masalah umum yang diperlukan untuk pengambilan keputusan). Konsep-konsep yang diberikan oleh defenisi tersebut sangat penting untuk memahami hubungan antara SPK dan pengetahuan.

Keen (1980) menerapkan istilah SPK untuk situasi dimana sistem 'final' dapat dikembangkan hanya melalui sutau proses pembelajaran dan evolusi yang adaftif. Jadi, ia mendefinisikan SPK sebagai suatu produk dari proses pengembangan dimana pengguna SPK, pembangun SPK, dan SPK itu sendiri mampu mempengaruhi satu dengan yang lainnya, dan menghasilkan evolusi sistem dan pola-pola penggunaan.Secara umum, sistem penunjang keputusan (SPK) membantu dalam pengambilan keputusan terhadap beberapa alternatif.

\subsection{Weighted Product}

Metode Weighted Product adalah salah satu metode penyelesaian pada masalah MADM. Metode ini mengevaluasi beberapa alternatif terhadap sekumpulan atribut atau kriteria, dimana setiap atribut saling tidak bergantung satu dengan yang lainnya (Kusumadewi, 2006).

Metode weighted product menggunakan perkalian untuk menghubungkan rating atribut, dimana rating setiap atribut harus dipangkatkan terlebih dahulu dengan bobot atribut yang bersangkutan (Yoon, 1989). Proses ini sama halnya dengan proses normalisasi. Preferensi untuk alternatif Ai diberikan sebagai berikut:

$$
S_{i}=\prod_{j=1}^{n} X_{i j}{ }^{w_{j}}
$$

Dengan i $=1,2, \ldots, \mathrm{m}$; dimana :

$\mathrm{S} \quad$ menyatakan preferensi alternatif dianalogikan sebagai vector $\mathrm{S}$

$\mathrm{X}$ menyatakan nilai kriteria

W menyatakan bobot kriteria

i menyatakan alternatif

j menyatakan kriteria

n menyatakan banyaknya kriteria

$\sum w_{j}=1$

$\mathbf{W}_{\mathrm{j}}$ adalah pangkat bernilai positif untuk atribut keuntungan dan bernilai negatif untuk atribut biaya.

Preferensi relatif dari setiap alternatif diberikan sebagai berikut :

$$
V_{i}=\frac{\prod_{j=1}^{n} x_{i j}{ }^{w_{j}}}{\prod_{j=1}^{n}\left(X_{j}{ }^{*}\right)^{w_{j}}} \text { dimana } i=1,2, \ldots, m
$$

dimana 


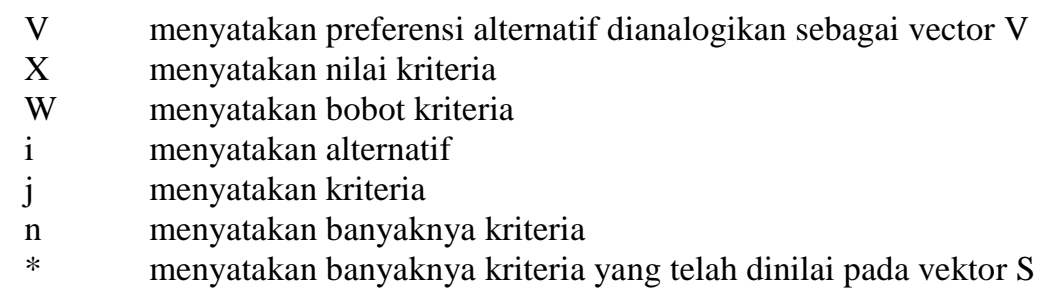

\subsubsection{Algoritma Metode Weighted Product}

Algoritma weighted product adalah tahapan metode penyelesaian dari masalah MADM. Metode weighted product mengevaluasi $\mathrm{m}$ alternatif $A_{i}(i=1,2, \ldots, m)$ terhadap sekumpulan atribut atau kriteria $C_{j}(j=1,2, \ldots, n)$, dimana setiap atribut saling tidak bergantung satu dengan yang lainnya. Matriks keputusan setiap alternatif terhadap setiap atribut $\mathrm{X}$ diberikan sebagai :

$$
X=\left[\begin{array}{ccc}
x_{11} & \ldots & x_{1 n} \\
\vdots & \ddots & \vdots \\
x_{1 m} & \cdots & x_{m n}
\end{array}\right]
$$

dimana $X_{i j}$ merupakan rating kinerja alternatif ke-i terhadap atribut ke-j. 1 menunjukan matriks keputusan setiap alternatif terhadap setiap atribut dalam penulisan berbentuk tabel yang berisi rating kinerja.

Tabel 1. Rating Kinerja

\begin{tabular}{|l|l|l|l|l|}
\hline $\begin{array}{l}\text { Kriteria } \\
\text { Alternatif }\end{array}$ & $\mathrm{C}_{1}$ & $\mathrm{C}_{2}$ & $\ldots \ldots$ & $\mathrm{C}_{\mathrm{n}}$ \\
\hline $\mathrm{A}_{1}$ & & & $\ldots$ & \\
\hline $\mathrm{A}_{2}$ & $\mathrm{X}_{11}$ & $\mathrm{X}_{12}$ & $\ldots \ldots$ & $\mathrm{X}_{1 \mathrm{n}}$ \\
\hline$\vdots$ & $\mathrm{X}_{21}$ & $\mathrm{X}_{22}$ & $\ldots \ldots$ & $\mathrm{X}_{2 \mathrm{n}}$ \\
\hline$:$ & $:$ & $\vdots$ & $\vdots$ & $\vdots$ \\
\hline $\mathrm{A}_{\mathrm{m}}$ & $:$ & $:$ & $:$ & $:$ \\
\hline
\end{tabular}

Nilai bobot yang menunjukkan tingkat kepentingan relatif setiap atribut, diberikan sebagai, W:

$$
W=\left\{w_{1}, w_{2}, \ldots, w_{n}\right\}
$$

Secara singkat, algoritma dari metode weighted product ini adalah sebagai berikut :

1. Melakukan normalisasi bobot untuk menghasilkan nilai $\sum_{j=1}^{n} w_{j}=1$. dimana $\mathrm{j}=1,2, \ldots, \mathrm{n}$ adalah banyak alternatif.

2. Menentukan kategori dari masing-masing kriteria, apakah termasuk ke dalam kriteria keuntungan atau kriteria biaya.

3. Menentukan nilai vektor S dengan mengalikan seluruh kriteria bagi sebuah alternatif dengan bobot sebagai pangkat positif untuk kriteria keuntungan dan bobot berfungsi sebagai pangkat negatif pada kriteria biaya.

4. Menentukan nilai vektor $\mathrm{V}$ yang akan digunakan untuk perangkingan.

5. Membandingkan nilai akhir dari vektor $\mathrm{V}$.

6. Menentukan urutan alternatif terbaik yang akan menjadi keputusan.

\section{METODE PENELITIAN}

\subsection{Analisis Kebutuhan Input}

Adapun Inputkriteria yang digunakan untuk melakukan proses pengambilan keputusan ditunjukkan pada tabel 2 .

Tabel 2. Analisis Kebutuhan Input

\begin{tabular}{ll}
\hline No & Kriteria \\
\hline 1 & Views \\
2 & Answers \\
3 & Rangking Alexa \\
4 & Tanggal Posting \\
\hline
\end{tabular}


Tabel 2 menjelaskan bahwa proses pengambilan keputusan yang mempengaruhi pemilihan rekomendasi forum ada beberapa kriteria yaitu Views (banyaknya yang melihat), Answer (jawaban) mempengaruhi interaktifitas forum, rangking alexa, Alexa merupakan suatu situs yang menyediakan sarana untuk mendapatkan informasi tentang peringkat suatu situs, beberapa orang mendasari kesuksesan website atau blog mereka dari bagusnya ranking mereka di alexa, semakin kecil nilai alexa rank anda semakin bagus posisi peringkat anda di alexa.Forum-forum yang diambil menggunakan perangkingan global bukan lokal atau Indonesia saja. Kriteria rangking alexa dipakai untuk merekomendasi forum yang menandakan kesuksesan peringkat suatu situs, dan kriteria tanggal posting untuk menandakan forum yang update. Kriteria-kriteria tersebut dipakai sehingga nantinya akan dihasilkan output yang berasal dari kelayakan alternatif rekomendasi yang dihasilkan dari proses perangkingan.

\subsection{AnalisisKebutuhan Output}

Output yang dihasilakan dari alternatif yang mempunyai nilai tertinggi dari pada nilai alternatif yang lain. Hasil yang dikeluarkan oleh program adalah nilai setiap kriteria yang ada, karena dalam setiap kriteria memiliki nilai bobot yang berbeda dengan kriteria yang lainnya

\subsection{Flowchart}

Data yang sudah didapat akan diurutkan berdasarkan bobot nilai dari setiap hasil pencarian. Untuk menghitung bobot nilai tersebut digunakan metode weighted product. Flowchart proses perhitungan menggunakan metode weighted product ditunjukkan pada Gambar 1.

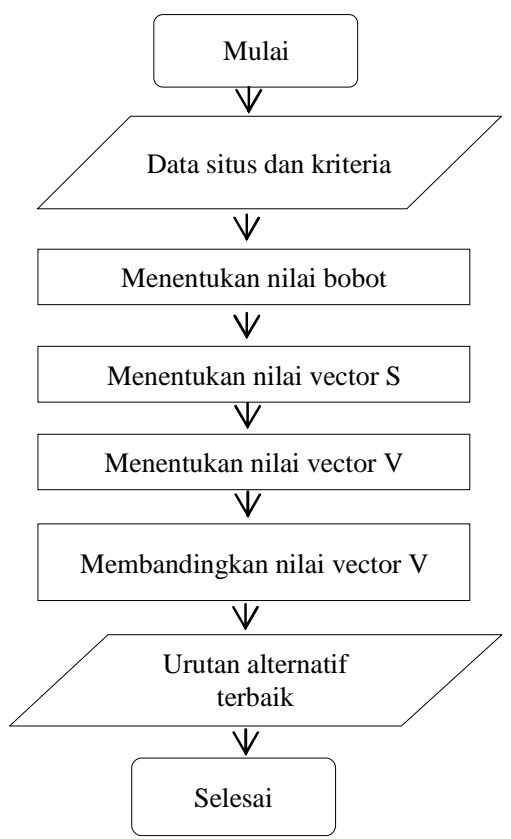

Gambar 1. Flowchart Metode Weighted product

\section{HASIL DAN PEMBAHASAN}

Adapun forum yang akan dirangking pada navigasi mahasiswa adalah sebagai berikut:

a. E-Learning Forum

- Programming

1. programmingforums.org

2. sekolahkoding.com

3. https://stackoverflow.com/

4. https://www.programmersheaven.com/

- Jaringan

1. http://www.networking-forum.com/

2. http://www.forummikrotik.com/

3. http://www.techsupportforum.com/forums/f134/

4. https://forums.techguy.org/forums/networking.53/

- Desain Grafis

1. http://insight.design/forum/ 
2. http://www.graphicdesignforum.com/forum/

3. graphicdesignforums.co.uk

b. Perangkingan Alexa Global

Adapun perangkingan forum di atas sebagai berikut:

Tabel 3. Komposisi Perangkingan Page Range Alexa

\begin{tabular}{|c|c|}
\hline PROGRAMMING & \\
\hline \multirow[t]{2}{*}{ programmingforums.org } & 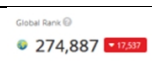 \\
\hline & $\begin{array}{l}20 \\
=59,460\end{array}$ \\
\hline \multirow[t]{2}{*}{ sekolahkoding.com } & 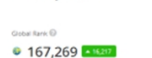 \\
\hline & $-2,725$ \\
\hline \multirow[t]{2}{*}{ https://stackoverflow.com/ } & $\begin{array}{ll}-12 \\
0\end{array}$ \\
\hline & $=49$ \\
\hline \multirow[t]{2}{*}{ https://www.programmersheaven.com/ } & 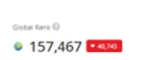 \\
\hline & $=35$ \\
\hline \multicolumn{2}{|l|}{ DESAIN GRAFIS } \\
\hline \multirow[t]{2}{*}{ http://insight.design/forum/ } & 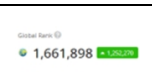 \\
\hline & $-40,983$ \\
\hline \multirow[t]{2}{*}{ http://www.graphicdesignforum.com/forum/ } & 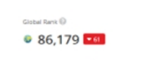 \\
\hline & $=33,491$ \\
\hline \multirow[t]{2}{*}{ GRAPHICDESIGNFORUMS.CO.UK } & ond \\
\hline & 117,219 \\
\hline \multicolumn{2}{|l|}{ JARINGAN } \\
\hline \multirow[t]{2}{*}{ http://www.networking-forum.com/ } & 204,358 \\
\hline & $=168,397$ \\
\hline \multirow[t]{2}{*}{ http://www.forummikrotik.com/ } & 245.209 \\
\hline & $-5,091$ \\
\hline \multirow[t]{2}{*}{ http://www.techsupportforum.com/forums/f134/ } & - 14,760 \\
\hline & $\$ 7,573$ \\
\hline \multirow[t]{2}{*}{ https://forums.techguy.org/forums/networking.53/ } & 0 \\
\hline & $=9,223$ \\
\hline
\end{tabular}

Tabel 4. Komposisi Implementasi Weighted product

\begin{tabular}{lllll}
\hline Jenis & Bobot & $\begin{array}{l}\mathrm{W} \\
\text { bobot } \\
(\%)\end{array}$ & Kriteria & Jenis Cost/Benefit \\
\hline $\begin{array}{l}\text { Hot } \\
\text { threads }\end{array}$ & 1 & $11 \%$ & Views & Benefit \\
& 2 & $22 \%$ & Answers & Benefit \\
& 1 & $11 \%$ & Rank alexa & Benefit \\
Hot- & 5 & $56 \%$ & Last update/Tgl Posting & Benefit \\
reviews & 1 & $13 \%$ & Views & Benefit \\
& 1 & $25 \%$ & Rank alexa & Benefit \\
& 1 & $13 \%$ & Last update/Tgl Posting & Benefit \\
& 5 & $63 \%$ & Answers & Benefit \\
\hline
\end{tabular}


Pada prosentase hot-threads pada tabel 4 bertujuan untuk membuat kategori hot threads didasarkan pada faktor tanggal posting terbaru supaya member forum mendapatkan informasi-informasi terbaru, jawaban yang menunjukkan interaksi forum kemudian views dan ranking alexa global untuk mengetahui popularitas forum.

Pada prosentase hot reviews pada tabel 4 bertujuan untuk membuat kategori hot reviews didasarkan pada jawaban member forum supaya member lain mendapatkan informasi yang lebih banyak dari tema yang dicari, kemudian di ikuti oleh kriteria rank global alexa untuk popularitas forum, viewsdan last updatel tanggal posting. Adapun salah satu studi kasus perhitungan Weighted Productpada navigasi Hot Threadssebagai berikut:

Tabel 5. Tabel Data Hot Threads

\begin{tabular}{rllccrr}
\hline No & Nama & Forum & Views & Answer & $\begin{array}{r}\text { Rangking } \\
\text { Alexa }\end{array}$ & $\begin{array}{r}\text { Last } \\
\text { Update }\end{array}$ \\
\hline 1 & Judul 1 & stackoverflow & 4.035 .147 & 69 & 56 & 3 \\
2 & Judul 2 & stackoverflow & 3.587 .335 & 52 & 56 & 2 \\
3 & Judul 3 & stackoverflow & 856.085 & 40 & 56 & 1 \\
\hline
\end{tabular}

\section{Perbaikan bobot $\left(\mathrm{W}_{\mathrm{j}}\right)$}

$$
\begin{aligned}
& W j=\frac{W_{-} \text {Initj }}{\sum_{j=1}^{n} W_{-} \text {Init } j} \\
& W 1(\text { Views })=\frac{1}{1+2+1+5}=0.11 \\
& W 2(\text { Answers })=\frac{2}{1+2+1+5}=0.22 \\
& W 3(\text { Rangking Alexa })=\frac{1}{1+2+1+5}=0.11 \\
& W 4(\text { Last Update })=\frac{5}{1+2+1+5}=0.55
\end{aligned}
$$

\subsubsection{Menentukan Nilai Vektor $S_{-}$}

Setelah menentukan nilai bobot $\mathrm{W}$, langkah selanjutnya adalah menentukan nilai vektor $\mathrm{S}_{\mathrm{i}}$. Dimana data judul yang ada akan dipangkatkan dengan bobot dari masing-masing kriteria. Untuk kriteria keuntungan berpangkat positif. Rumus menghitung nilai vektor $S_{i}$ ditunjukkan pada persamaan 4

$$
\begin{aligned}
& \text { Menghitung vektor } \mathrm{S}_{\mathrm{i}} \\
& S_{i}=\prod_{j=1}^{n} X_{i j}{ }^{w_{j}}
\end{aligned}
$$

Beberapa perhitungan vektor $\mathrm{S}_{\mathrm{i}}$ berdasarkan data yang ada pada Tabel 5, antara lain:

$S 1=4035147^{0.11} \times 69^{0.22} \times 56^{0.11} \times 3^{0.55}=38.53$

$S 2=3587335^{0.11} \times 52^{0.22} \times 56^{0.11} \times 2^{0.55}=28.60$

$S 3=856.085^{0.11} \times 40^{0.22} \times 56^{-0.11} \times 1^{0.55}=15.75$ 


\subsubsection{Menentukan Nilai Vektor $V_{i}$}

Setelah menghitung nilai vektor $\mathrm{S}_{\mathrm{i}}$, langkah selanjutnya adalah menghitung nilai vektor $\mathrm{V}_{\mathrm{i}}$. Menghitung vektor $\mathrm{V}_{\mathrm{i}}$ adalah dengan cara membagi hasil masing-masing vektor $\mathrm{S}_{\mathrm{i}}$ dengan jumlah seluruh vektor $S_{i}$. Rumus menghitung nilai vektor $V_{i}$ ditunjukkan pada persamaan 5 .

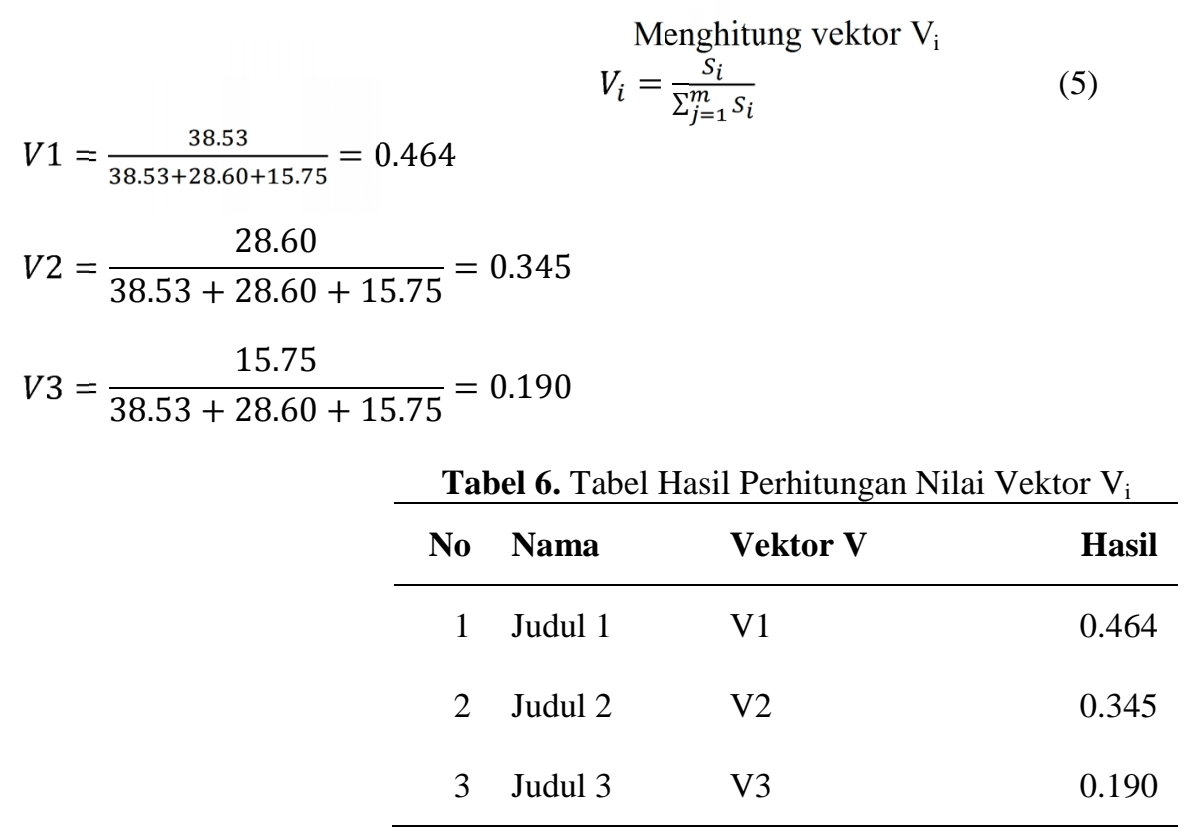

\subsubsection{Hasil Akhir}

Setelah semua data dihitung, langkah selanjutnya adalah pengurutan bobot nilai mulai dari hasil yang terbesar sampai hasil yang terkecil. Beberapa hasil pengurutan data judul yang ditunjukkan pada Tabel 7

Tabel 7. Hasil Pengurutan Hasil $\mathrm{V}_{\mathrm{i}}$

\begin{tabular}{|c|c|c|c|c|c|c|c|}
\hline No & Nama & Forum & Views & Answer & $\begin{array}{r}\text { Rangking } \\
\text { Alexa }\end{array}$ & Last Update & Hasil \\
\hline 1 & Judul 1 & stackoverflow & 4.035 .147 & 69 & 56 & 3 & 0.464 \\
\hline 2 & Judul 2 & stackoverflow & 3.587 .335 & 52 & 56 & 2 & 0.345 \\
\hline 3 & Judul 3 & stackoverflow & 856.085 & 40 & 56 & 1 & 0.190 \\
\hline
\end{tabular}

\subsection{Tampilan dan Pengujian}

A. Antarmuka Aplikasi

Pada antarmuka home, terdiri dari empat navigasi pokok berdasarkan profil pengguna yaitu mahasiswa, dosen, alumni dan circle (berdasarkan hobi).Antarmuka ditunjukkan pada Gambar 2. 


\section{AFO}

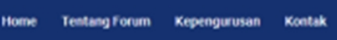

Tentukan forum Anda!
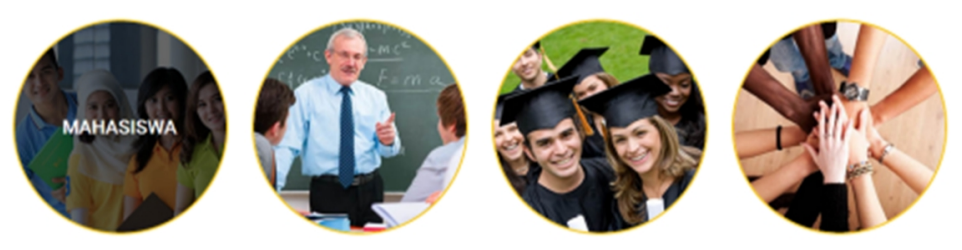

Gambar 2. Antarmuka Home Pencarian Forum

Ketika profile pengguna mahasiswa diklik akan ada 4 cara pencarian forum yaitu berdasarkan hot threads, hot reviews, pencarian dengan form dan pencarian berdasarkan kategori. Antarmuka ditunjukkan pada Gambar 3. Pada penelitian ini focus pada navigasi forum untuk mahasiswa.

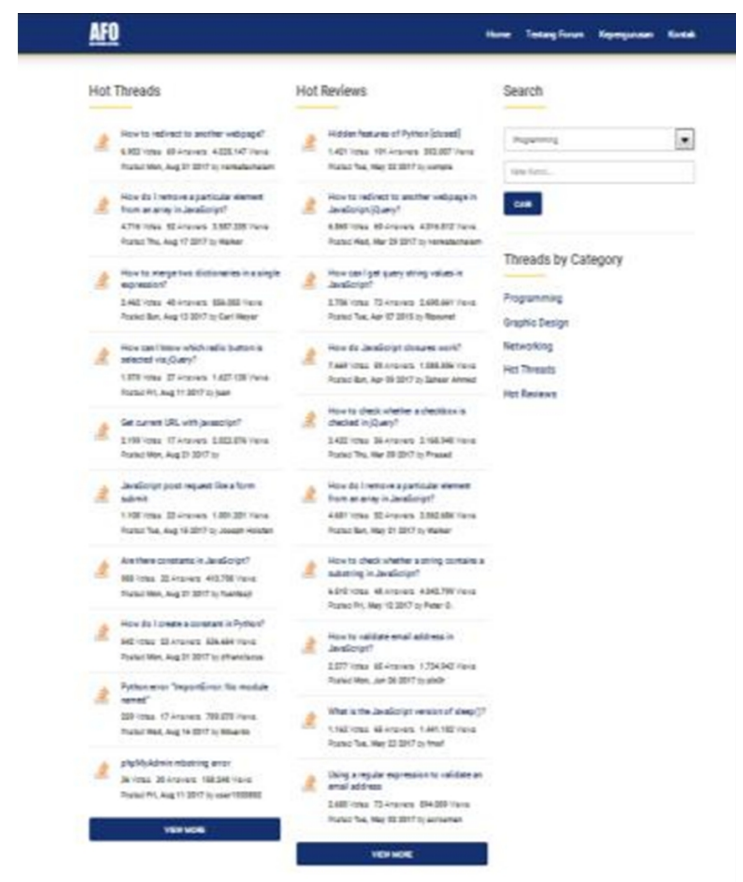

Gambar 3. Antarmuka Home Profil Mahasiswa

\section{B. Pengujian}

Pada tahap pengujian sistem digunakan proses verifikasi dan validasi. Proses verifikasi adalah menjawab pertanyaan apakah model matematis yang digunakan sudah menghasilkan nilai yang benar. Metode yang digunakan untuk verifikasi ini adalah membandingkan hasil keluaran sistem dengan perhitungan numeric (Daellenbach, 2005).Verifikasi juga diartikan menguji apakah semua modul dalam prototipe yang dirancang telah dapat berjalan dengan baik, hal ini dilakukan dengan menjalankan (melakukan simulasi) dengan 
menggunakan data hipotesis (Whitten, 2000). Setelah dilakukan simulasi hasil diperoleh terdapat pada tabel 8 dan hasil pengujian ditunjukkan pada Gambar 4, Gambar 5, Gambar 6, Gambar 7, Gambar 8.

Tabel 8. Hasil Pengujian

\begin{tabular}{lll}
\hline $\begin{array}{c}\text { Modul dalam } \\
\text { Prototipe }\end{array}$ & Pengujian ke- & \multicolumn{1}{c}{ Hasil Simulasi } \\
\hline Hot Threads 1 & 1 & Berhasil sesuai pembobotan kriteria \\
Hot Threads 2 & 2 & Berhasil sesuai pembobotan kriteria \\
Hot Threads 3 & 3 & Berhasil sesuai pembobotan kriteria \\
Hot Reviews & 4 & Berhasil sesuai pembobotan kriteria \\
\hline
\end{tabular}

Dari hasil empat kali pengujian, didapatkan akurasi sebesar $100 \%$ terhadap error yang muncul. Prosentase akurasi data pengujian $=\frac{4}{4} \cdot 100 \%=100 \%$

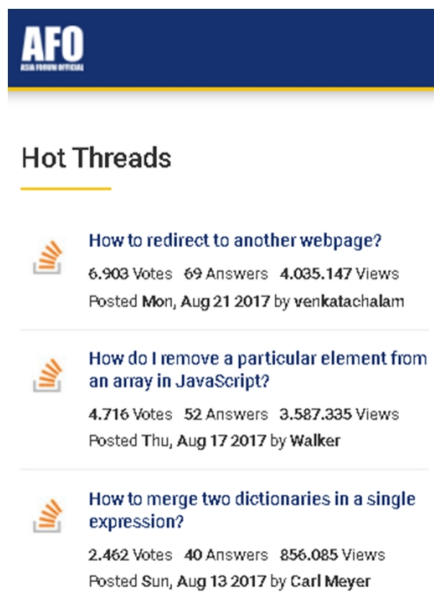

Gambar 4. Pengujian ke-1

Pada pengujian ke-1 pada Hot Threads, dimana forum yang dibandingkan adalah satu forum yaitu stackflow, tema yang direkomendasikan sudah terurut sesuai kriteria yaitu tanggal posting dimana pada pengujian sudah berurut dari tanggal 21 Agustus 2017, 17 Agustus 2017 dan 13 Agustus 2017 kemudian diikuti dengan kriteria answer sudah terurut dengan komposisi 69 answer, 52 answer, 42 answer, kriteria views dan rangking diberi pembobotan yang sama karena rangking forumnya sama sehingga kita bias melihat pada kriteria views yang sudah terurut secara rangking yaitu 4.035.147 views, 3.587 .335 views, dan 856.085 views.

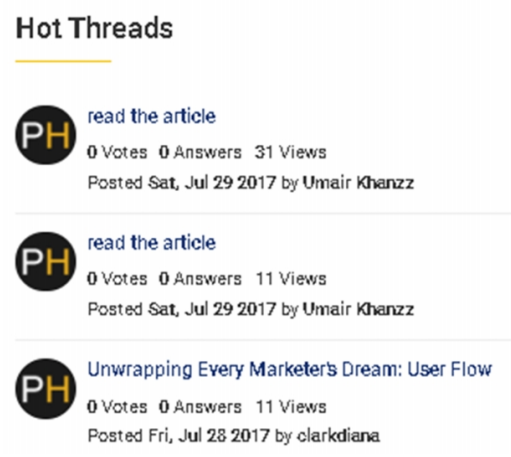

Gambar 5. Pengujian ke-2 
Sama halnya Gambar 4 Pada pengujian ke-2 ditunjukkan Gambar.5 Tanggal posting sudah terangking secara tertinggi sampai terendah diikuti jumlah jawaban yang sama-sama 0, dank arena views dan rangking dibuat sama pembobotannya sehingga kita tinggal melihat viewsnya yaitu sudah terurut juga berdasarkan nilai tertinggi.

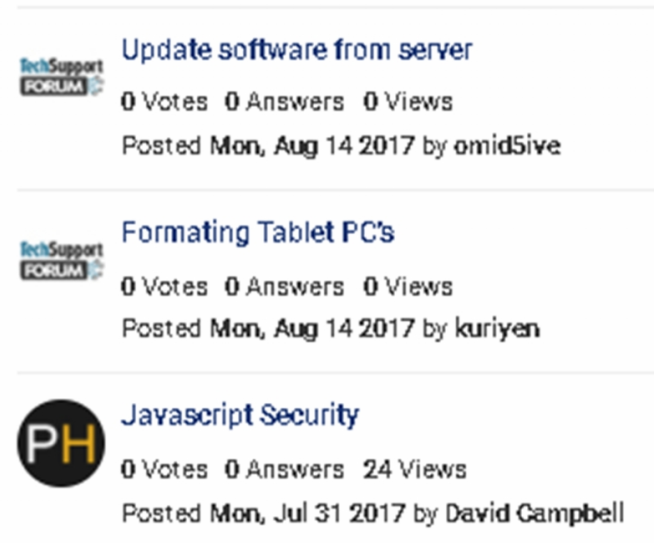

Gambar 6. Pengujian ke-3

Pada pengujian ke-3 kita mengujian hot treads forum dengan situs forum yang berbeda yaitu ditunjukkan pada Gambar 6, Urutan situs yang direkomendasikan sudah berurut berdasarkan tanggal posting sudha terurut dari nilai tertinggi sampai terendah diikuti, jumlah jawaban yang sama yaitu 0 answers, kemudian views dan rangking alexa yang ada pada pembobotan yang sama dimana karena situs forum http://www.techsupportforum.com/forums/f134/ menempati page global alexa 14.760 dan https://www.programmersheaven.com/ menempati page rank alexa 157.467 dimana posisi situs http://www.techsupportforum.com/forums/f134/ menempati jauh lebih tinggi pembobotannya daripada https://www.programmersheaven.com/ (dimana perangkingan global alexa semakin kecil semakin tinggi dan popular situsnya maka dari hasil percobaan ketiga posisi keduanya sudah terurut dari tertinggi ke yang rendah diikuti dengan views.

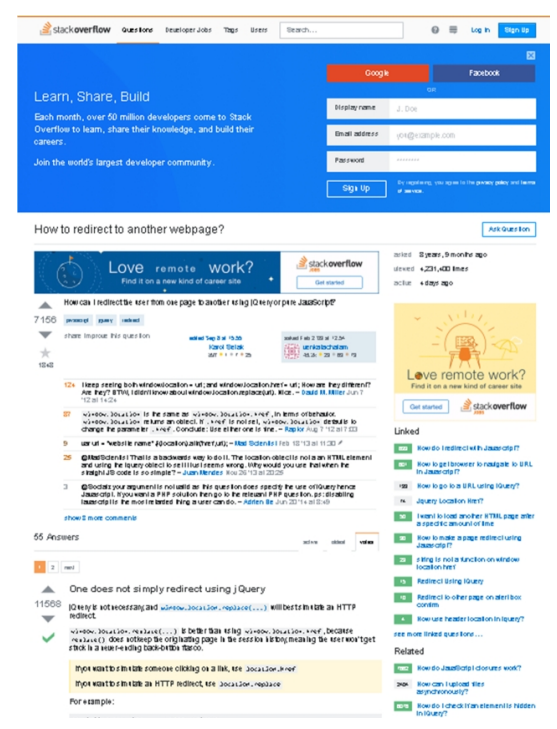

Gambar 7. Hasil OuputSalah Satu Hot Threads 


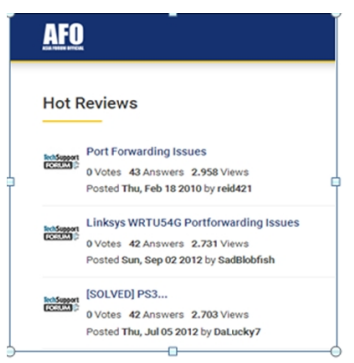

Gambar 8. Pengujian ke-4

Pada Pengujian hot reviewsyang ditunjukkan Gambar 8 kriteria pembobotan berbeda dengan hot threads dimana dirangking dari kriteria answer, rangking global alexa, view dan tanggal posting dengan posisi yang sama. Dari hasil hot reviews diatas perangkingannya sudah sesuai yaitu dari answer yang berurutan 43 answer, 42 answer, 42 answer kemudian diikuti rangking alexa yang tidak diperhitungkan karena masih dalam satu situs forum, views dengan urutan 2.958 views, 2.731 views, 2.703 views dan diikuti urutan tanggal posting yang dinilai kriteria paling bawah. Pada kasus pengujian ke-4 kriteria ke 4 yaitu tanggal posting tidak terlalu diperhatikan karena kalah dengan pembobotan jumlah jawaban.

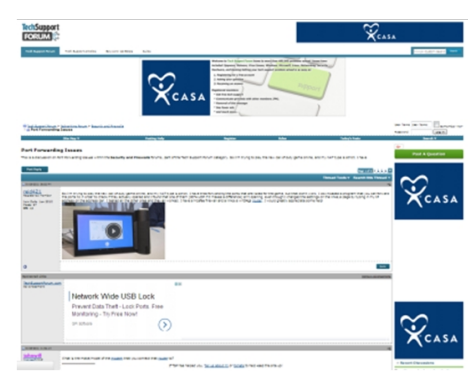

Gambar 9. Ilustrasi hasil ouputhot reviews

\section{KESIMPULAN}

Berdasarkan hasil dan pembahasan, maka kesimpulan yang dapat diambil adalah situs dengan dengan urutan paling atas memiliki nilai paling tinggi dan direkomendasikan ke mahasiswa dalam pemilihan forum dengan nilai prosentase akurasi sebesar $100 \%$ dengan metode pengujian validasi dan verifikasi sebanyak empat data yang diujikan sesuai pembobotan kriteria yang telah ditentukan.

\section{DAFTAR PUSTAKA}

Bishop, C. B., Bishop, M. B., Whitten, K. W., (2000), Standard and microscale experiment in general chemistry, Fourth edition, Saunders College Publishing, USA, 22-23

Bonczek, RH, dkk (1980), THE EVOLVING ROLES OF MODELS IN DECISION SUPPORT SYSTEMS, A Journal Of The Decision Science Institute, Volume 11,Issue 2, April 1980.

Daellenbach H. G. dan McNickle D. C. (2005) : Management Science: Decision Making through Systems Thinking, Palgrave Macmillan, Hampshire.

H. Yang and J. Tang. (2003). “Effects Of Social Network On Students'Performance: A Web-Based Forum Study In Taiwan,” vol. 7, no. 3, pp. 93-107

Jaya, Putra (2013). "Sistem Pendukung Keputusan Penentuan Bonus Karyawan Menggunakan Metode Weighted Product (WP) (Studi Kasus: PT. Gunung Sari Medan”. Pelita Informasi Budi Darma, Vol. 


$$
\text { V, No. 2, pp. 90-95. }
$$

Keen, P. G. W. (1980). Adaptive Design for Decision Support Systems, Data Base, Vol. 12, No. 1 dan 2.

Kusumadewi, S., et.all. (2006). "Fuzzy Multi-Attribute Decision Making (FUZZY MADM)”, Graha Ilmu, Yogyakarta

L. Shi, B. Sun, L. Kong, and Y. Zhang. (2009). “Web Forum Sentiment Analysis based on Topics,” pp. 148153

Little, J. D. C. (1970). Models and Managers: The Concept of a Decision Calculus, Management Science, Vol. 16, N0. 8.

Rani,Sasika. (2014). "Sistem Pendukung Keputusan Pemilihan Sepeda Motor Berbasis Web Dengan Metode Weighted Product”. Skripsi. Teknik informatika, STMIK Budidarma Medan.

Turban, Efraim, et al.(2005).Decision Support Systems and Intelligent Systems.7th Ed. New Jersey. Pearson Education. 